\title{
ANALISA PERBANDINGAN TAHANAN PEMBUMIAN PERALATAN ELEKTRODA PASAK PADA GEDUNG LABORATORIUM TEKNIK UNIVERSITAS BORNEO TARAKAN
}

\author{
Achmad Budiman \\ Program Studi Teknik Elektro, Universitas Borneo Tarakan \\ Jalan Amal Lama No.1 Tarakan \\ Email : $\underline{\operatorname{achmad1177@gmail.com~}}$
}

\begin{abstract}
Abstrak - Sistem pembumian yang kurang baik dapat menyebabkan kerusakan pada peralatan listrik. Resiko yang ditimbulkan adalah arus lebih tidak dapat disalurkan secara maksimal kembali ke bumi. Semakin kecil nilai tahanan pembumian maka semakin baik sistem pembumiannya. Pada kondisi tanah tertentu, nilai tahanan pembumian juga dipengaruhi oleh kedalaman penanaman elektroda. Hasil pengukuran nilai tahanan pembumian elektroda pasak tunggal dengan panjang masing-masing $1,5 \mathrm{~m}$ dan 2 $\mathrm{m}$, diameter $0,045 \mathrm{~m}$, masing-masing kedalaman $3 \mathrm{~m}$ dan 3,25 m pada Gedung Laboratorium Teknik Universitas Borneo Tarakan berturut-turut diperoleh nilai $\mathrm{R}_{\text {(pembumian) }}$ sebesar $12,76 \Omega$ dan $12 \Omega$ sedangkan hasil perhitungan diperoleh nilai $\mathrm{R}_{\text {(pembumian) }}$ sebesar $12,85 \Omega$ dan 12,10 $\Omega$ dengan nilai rata-rata tahanan jenis tanah liat berlumpur $(\rho)$ sebesar $38,58 \Omega-\mathrm{m}$ dan $38,84 \Omega-\mathrm{m}$. Pemasangan elektroda pasak $1,5 \mathrm{~m}$ minimal 3 buah secara paralel mempunyai nilai $R_{\text {(pembumian) }}$ sebesar $4,28 \Omega$ memenuhi Persyaratan Umum Instalasi Listrik $\leq 5 \Omega$ dan jarak minimum pemasangan antar elektroda sebesar 2 (dua) kali panjangnya.
\end{abstract}

Kata kunci : elektroda pasak tunggal, tahanan jenis, tahanan pembumian.

\begin{abstract}
Earthing systems are less well able to cause damage to electrical equipment. The risks are more current can not be optimally channeled back to earth. The smaller the resistance value, The better the earthing system. In certain soil conditions, grounding resistance value is also influenced by the depth of planting electrodes. The measurement results one ground rod resistance value with each length of $1.5 \mathrm{~m}$ and $2 \mathrm{~m}$, diameter $0.045 \mathrm{~m}$, respectively depth of $3 \mathrm{~m}$ and $3.25 \mathrm{~m}$ in Building Engineering Laboratory of the University of Borneo Tarakan successively obtained values of R (earthing) amounted to $12.76 \Omega$ and $12 \Omega$ while the calculation, the value of R (earthing) of 12.85 and $12.10 \Omega \Omega$ with the average value of muddy clay resistivity $(\rho)$ of $38.58 \Omega-\mathrm{m}$ and $38.84 \Omega-\mathrm{m}$. The installation of a ground rod $1,5 \mathrm{~m}$ of minimum 3 pieces in parallel has an R (earthing) value of $4.28 \Omega$ complied with General Term Electrical Installation (PUIL 2000) $\leq 5 \Omega$ and minimum installation distance between electrodes of 2 (two) times in length.
\end{abstract}

Keywords : single rod electrodes, resistivity, earthing resistance.

Copyright $\odot 2017$ JNTE. All rights reserved

\section{PENDAhUluan}

Sistem pembumian yang kurang baik dapat mengakibatkan arus bocor tidak dapat disalurkan secara maksimal kembali ke bumi sehingga menimbulkan resiko keamanan dalam hal penggunaan peralatan listrik. Semakin kecil nilai tahanan pembumian maka semakin baik sistem pembumiannya. Pada kondisi tanah tertentu, nilai tahanan pembumian juga dipengaruhi oleh kedalaman penanaman elektroda [6]. Sehingga sistem pembumian yang baik sangatlah penting.

Pembumian menurut Persyaratan Umum Instalasi Listrik adalah penghubungan suatu titik sirkit listrik atau suatu penghantar yang bukan bagian dari sirkit listrik, dengan bumi menurut cara tertentu dan Nilai tahanan pembumian yang dipersyaratkan adalah $\leq 5 \Omega[2]$.

Pencapaian dalam penelitian ini adalah mengetahui kedalaman optimal elektroda pasak tunggal Gedung Laboratorium Teknik Universitas Borneo Tarakan dengan nilai tahanan pembumian $\leq 5 \Omega$ dan selisih antara pengukuran dan perhitungan tidak lebih dari $1 \%$.

Sistem pembumian (grounding system) adalah suatu perangkat instalasi yang berfungsi untuk melepaskan arus lebih atau arus gangguan ke dalam bumi salah satu melepas muatan arus petir [1]. Tingkat kehandalan sebuah grounding ada dinilai konduktivitas logam terhadap tanah 
yang ditancapinya. Semakin konduktif tanah terhadap benda logam maka semakin baik. Kelayakan grounding harus bisa mendapatkan nilai tahanan sebaran maksimal $5 \mathrm{ohm}$ dengan menggunakan earth grunding tester. Namun begitu untuk daerah yang resistansi jenis tanahnya sangat tinggi resistansi pembumian total seluruh sistem boleh mencapai $10 \mathrm{ohm}$ [2].

Untuk mengetahui nilai-nilai tahanan jenis tanah yang akurat harus dilakukan pengukuran secara langsung pada lokasi yang digunakan untuk sistem pembumian karena struktur tanah yang sesungguhnya tidak sederhana yang diperkirakan, untuk setiap lokasi berbeda mempunyai tahanan jenis yang berbeda [3].

Elektroda pembumian adalah penghantar yang ditanam dalam tanah dan membuat kontak langsung dengan tanah. Penghantar pembumian yang tidak berisolasi ditanam dalam tanah dianggap sebagai elektroda pembumian. Ukuran minimum elektroda pembumian dapat dilihat pada Tabel 1 [2].

Tabel 1. Ukuran minimum elektroda pembumian

\begin{tabular}{|c|c|c|c|}
\hline $\begin{array}{l}\text { Bahan } \\
\text { jenis } \\
\text { elektroda }\end{array}$ & $\begin{array}{c}\text { Baja } \\
\text { digalvanisasi } \\
\text { dengan proses } \\
\text { pemanasan }\end{array}$ & $\begin{array}{c}\text { Baja berlapis } \\
\text { tembaga }\end{array}$ & Tembaga \\
\hline $\begin{array}{l}\text { Elektroda } \\
\text { batang }\end{array}$ & $\begin{array}{c}\text { Pipa baja } 25 \mathrm{~mm} \\
\text { Baja profil }(\mathrm{mm}) \\
\text { L } 65 \times 65 \times 7 \\
\text { U } 6,5 \\
\text { T } 6 \times 50 \times 3 \\
\text { Batang profil lain } \\
\text { yang setaraf }\end{array}$ & $\begin{array}{c}\text { Baja } \\
\text { berdiameter } \\
15 \mathrm{~mm} \\
\text { dilapisi } \\
\text { tembaga } \\
\text { setebal } 250 \\
\mu \mathrm{m}\end{array}$ & \\
\hline
\end{tabular}

Elektroda batang terbuat dari batang logam bulatatau baja profil yang dipancang/ditancapkan kedalam tanah dan salah satunya lancip dengan kelancipan $(45 \pm 5)^{\circ}$ [7] dan semakin dalam penanaman elektroda batang maka hasil yang didapat akan semakin $\mathrm{kecil} / \mathrm{semakin}$ baik [8].

Tujuan utama pembumian adalah menciptakan jalur yang low impedence (tahanan rendah) terhadap permukaan bumi untuk gelombang listrik dan transient voltage. Penerangan, arus listrik, circuit switching dan electrostatic discharge adalah penyebab umum dari adanya sentakan listrik atau transient voltage [5].
Untuk melakukan perhitungan tahanan pembumian elektroda pasak tunggal menggunakan persamaan dalam IEEE Std 1422007 yang dikembangkan oleh Profesor H. B. Dwight dari Institut Teknologi Massachusetts [4]:

$R=\frac{\rho}{2 \pi L} \cdot\left(\operatorname{Ln}\left[\frac{4 L}{a}\right]-1\right)$

\section{Dengan,}

$\rho=$ Tahanan jenis tanah $(\mathrm{ohm}-\mathrm{cm})$

$\mathrm{L}=$ Panjang elektroda pasak $(\mathrm{cm})$

$\mathrm{a}=$ Jari-jari elektroda pasak $(\mathrm{cm})$

$\mathrm{R}=$ Tahanan pembumian untuk elektroda $\operatorname{pasak}(\mathrm{ohm})$

Untuk memperkecil tahanan pembumian maka digunakan persamaan hubung paralel dengan jarak antara elektroda tersebut minimum harus dua kali panjangnya [2] :

$\frac{1}{R_{\text {Total }}}=\frac{1}{R_{1}}+\frac{1}{R_{2}}+\cdots+\frac{1}{R_{N}}$

\section{Dengan,}

$\mathrm{R}_{\text {Total }}=$ Total tahanan pembumian untuk elektroda pasak(ohm)

$\mathrm{R}_{1}=$ Tahanan pembumian untuk elektroda pasak ke-1 (ohm)

$\mathrm{R}_{2}=$ Tahanan pembumian untuk elektroda pasak ke-2 (ohm)

$\mathrm{R}_{\mathrm{N}}=$ Tahanan pembumian untuk elektroda pasak ke-N (ohm)

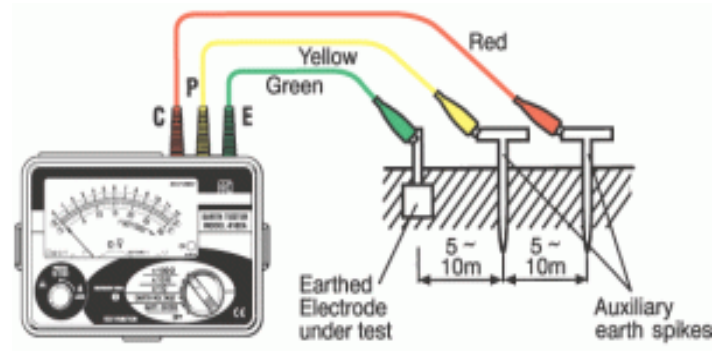

Gambar 1. Alat ukur grounding earth tester

Cara menggunakan alat ukur tahanan pembumian dengan Earth Tester:

1. Periksa kondisi kabel grounding $\mathrm{BC}$ yang akan diukur. Bila kotor bersihkan dahulu permukaan kabel tersebut dengan lap bersih/ kertas amplas, agar jepitan kabel probe dapat menyentuh langsung bagian permukaan 
tembaga yang sudah bersih dan untuk mencegah terjadinya kesalahan pembacaan pada alat ukur.

2. Periksa kondisi dan perlengkapan penunjang alat ukur digital earth resistance digital.

3. Earth Tester mempunyai tiga kabel diantaranya adalah kebel merah, kuning dan hijau.

4. Silahkan hubungkan kabel ke Earth Tester dengan warna yang sudah di tentukan pada alat ukur.

5. Hubungkan kabel merah serta kuning ke tanah dengan masing-masing jarak kurang lebih 5-10 meter dari pembumian atau grounding.

6. Hubungkan juga kabel hijau ke grounding yang sudah terpasang.

7. Lakukan pengukuran grounding (tahanan pembumian) dengan memutar knob alat ukur pada posisi $200 \mathrm{ohm}$ atau $2000 \mathrm{ohm}$ tergantung dari kondisi tanah pada area setempat yang akan diukur.

8. Kemudian tekan tombol Tester untuk mengetahui resistansi grounding biasanya berwarna kuning/ merah dan pada displai alat ukur akan muncul nilai tahanan pembumian.

9. Selesai, nilai resistansi grounding sudah diketahui.

\section{METODOLOGI PENELITIAN}

Obyek penelitian ini adalah Tanah di Halaman Gedung Laboratorium Teknik Universitas Borneo Tarakan Propinsi Kalimantan Utara dengan fokus pada Sistem Pembumian Elektroda Pasak Tunggal. Alat dan bahan yang digunakan untuk melakukan pengukuran pada obyek penelitian adalah:

1. Digital Earth Tester model 4105A;

2. Satu buah Pasak Elektroda dengan panjang $1,5 \mathrm{~m}$ berdiameter $0,045 \mathrm{~m}$;

3. Satu buah Pasak Elektroda dengan panjang 2 $\mathrm{m}$ berdiameter $0,045 \mathrm{~m}$;

4. Palu / Martil, Tang Jepit, Meteran, Bor Tangan (Hand Boring);

5. Satu set pengujian kadar air $(w)$;

6. Satu unit komputer.

Penelitian ini dilakukan dengan tahapantahapan berikut :

1. Studi pustaka dengan mengadakan studi literatur baik dari buku-buku maupun penelitian sebelumnya.
2. Observasi keadaan di lapangan untuk koleksi data.

3. Melakukan pengujian kadar air dari sampel tanah di laboratorium.

4. Melakukan pengukuran tahanan pembumian di lapangan.

5. Analisa data dan melakukan perbandingan hasil antara pengukuran data perhitungan.

6. Kesimpulan dan Saran.

\section{HASIL DAN PEMBAHASAN}

Hasil pengujian kadar air ( $w$ ) yang dilakukan di Laboratorium Mekanika Tanah Jurusan Teknik Sipil Fakultas Teknik Universitas Borneo Tarakan adalah 274,18\% pada Tabel 2 dan Tabel 3 memiliki hasil 300,84\%, sedangkan pada Tabel 4 memiliki hasil 350,22\%, menunjukkan bahwa kadar air (w) semakin tinggi pada kedalaman tanah tertentu.

Berikut ini tabel hasil uji kadar air tanah liat berlumpur di lokasi penelitian.

Tabel 2. Hasil uji kadar air (w) tanah liat berlumpur untuk kedalaman $1 \mathrm{~m}$.

\begin{tabular}{|c|c|c|c|}
\hline Nomor Sampel & $\mathbf{I}$ & II & III \\
\hline $\begin{array}{l}\text { Berat Cawan + Tanah } \\
\text { Basah }\left(\mathrm{W}_{1}\right) \text { gram }\end{array}$ & 154,5 & 156,3 & 153.7 \\
\hline $\begin{array}{l}\text { Berat Cawan + Tanah } \\
\text { Kering }\left(\mathrm{W}_{2}\right) \text { gram }\end{array}$ & 118,5 & 118,7 & 110,5 \\
\hline $\begin{array}{c}\text { Berat Air }\left(\mathrm{W}_{1}-\mathrm{W}_{2}\right) \\
\text { gram }\end{array}$ & 36 & 37,6 & 43,2 \\
\hline Berat Cawan (W3) gram & 10,1 & 10,2 & 9,9 \\
\hline $\begin{array}{c}\text { Berat Tanah Kering }\left(\mathrm{W}_{2}\right. \\
\left.-\mathrm{W}_{3}\right) \text { gram }\end{array}$ & 108,4 & 108,5 & 100,6 \\
\hline $\begin{array}{c}\text { Kadar Air }(\mathrm{W})=\left(\mathrm{W}_{1}-\right. \\
\left.\mathrm{W}_{2}\right) /\left(\mathrm{W}_{2}-\mathrm{W}_{3}\right) \times 100 \%\end{array}$ & $301,11 \%$ & $288,56 \%$ & $232,87 \%$ \\
\hline Rata-rata & \multicolumn{3}{|c|}{$274,18 \%$} \\
\hline
\end{tabular}

Tabel 3. Hasil uji kadar air (w) tanah liat berlumpur untuk kedalaman $2 \mathrm{~m}$.

\begin{tabular}{|c|c|c|c|}
\hline Nomor Sampel & I & II & III \\
\hline $\begin{array}{c}\text { Berat Cawan }+ \text { Tanah Basah }\left(\mathrm{W}_{1}\right. \\
\text { gram }\end{array}$ & 175,8 & 157,2 & 146,9 \\
\hline $\begin{array}{c}\text { Berat Cawan + Tanah Kering } \\
\left(\mathrm{W}_{2}\right) \text { gram }\end{array}$ & 131,5 & 125,8 & 109,9 \\
\hline Berat Air $\left(\mathrm{W}_{1}-\mathrm{W}_{2}\right)$ gram & 44,3 & 31,4 & 37 \\
\hline Berat Cawan (W3) gram & 10,9 & 11,3 & 11,7 \\
\hline $\begin{array}{c}\text { Berat Tanah Kering }\left(\mathrm{W}_{2}-\mathrm{W}_{3}\right) \\
\text { gram }\end{array}$ & 120,6 & 114,5 & 98,2 \\
\hline $\begin{array}{c}\text { Kadar Air }(\mathrm{W})=\left(\mathrm{W}_{1}-\mathrm{W}_{2}\right) / \\
\left(\mathrm{W}_{2}-\mathrm{W}_{3}\right) \times 100 \%\end{array}$ & $272,23 \%$ & $364,65 \%$ & $265,65 \%$ \\
\hline Rata-rata & & $300,84 \%$ & \\
\hline
\end{tabular}


Tabel 4. Hasil uji kadar air (w) tanah liat berlumpur untuk kedalaman $3 \mathrm{~m}$.

\begin{tabular}{|c|c|c|c|}
\hline Nomor Sampel & I & II & III \\
\hline $\begin{array}{c}\text { Berat Cawan + Tanah Basah } \\
\text { (W1) gram }\end{array}$ & 153,3 & 156,2 & 138,7 \\
\hline $\begin{array}{c}\text { Berat Cawan + Tanah Kering } \\
\text { (W2) gram }\end{array}$ & 118,1 & 119,2 & 115,8 \\
\hline Berat Air (W1 - W2) gram & 35,2 & 37 & 22,9 \\
\hline Berat Cawan (W3) gram & 11,4 & 10,8 & 11,7 \\
\hline $\begin{array}{c}\text { Berat Tanah Kering (W2 - W3 } \\
\text { gram }\end{array}$ & 106,7 & 108,4 & 104,1 \\
\hline $\begin{array}{c}\text { Kadar Air (W) }=\left(\mathrm{W}_{1}-\mathrm{W}_{2}\right) \\
\left.\text { (W2 }-\mathrm{W}_{3}\right) \mathrm{x} 100 \%\end{array}$ & $303,12 \%$ & $292,97 \%$ & $454,58 \%$ \\
\hline Rata-rata & \multicolumn{3}{|c|}{$350,22 \%$} \\
\hline
\end{tabular}

Sumber : Laboratorium Teknik FT-UBT

Kadar air pada tanah dapat mempengaruhi nilai $\mathrm{R}_{\text {(pembumian), menunjukkan bahwa }}$ penempatan elektroda pembumian pada kedalaman tanah yang memiliki kadar air $(w)$ tinggi maka memperkecil nilai tahanan pembumian dan air merupakan konduktor yang baik dalam mengalirkan arus listrik.

Pengukuran tahanan tanah liat berlumpur pada lokasi Gedung Laboratorium Teknik Universitas Borneo Tarakan dilakukan dengan cara membenamkan elektroda pasak yang memiliki panjang elektroda pasak $1,5 \mathrm{~m}$ dan $2 \mathrm{~m}$ berdiameter $0,045 \mathrm{~m}$ dalam beberapa variasi kedalaman dan membaca hasil pengukuran tersebut pada alat ukur Digital Earth Tester model 4105A seperti yang disajikan dalam tabel berikut ini :

Tabel 5. Hasil pengukuran $R_{\text {(pembumian) }}$ untuk Elektroda Pasak Tunggal $1,5 \mathrm{~m}$.

\begin{tabular}{|c|c|c|c|c|}
\hline \multirow{2}{*}{$\begin{array}{c}\text { Kedalaman } \\
\text { Elektroda } \\
(\mathrm{m})\end{array}$} & \multicolumn{4}{|c|}{ Nilai Pengukuran $\mathrm{R}_{\text {(pembumian) }}(\Omega)$} \\
\cline { 2 - 5 } & $\mathrm{I}$ & $\mathrm{II}$ & $\mathrm{III}$ & $\begin{array}{c}\text { Rata- } \\
\text { rata }\end{array}$ \\
\hline 2,25 & 14,7 & 14,6 & 14,9 & 14,73 \\
\hline 2,5 & 13,3 & 13,9 & 14 & 13,73 \\
\hline 2,75 & 12,9 & 13,1 & 13,3 & 13,1 \\
\hline 3 & 12,6 & 12,8 & 12,9 & 12,76 \\
\hline 3,25 & 12,3 & 12,4 & 12,6 & 12,43 \\
\hline 3,5 & 12 & 12 & 12,1 & 12 \\
\hline 3,75 & 11,8 & 11,5 & 11,4 & 11,56 \\
\hline 4 & 11,3 & 11,1 & 11 & 11,13 \\
\hline 4,25 & 10,3 & 10,4 & 10,6 & 10,43 \\
\hline 4,5 & 10 & 10,1 & 10,3 & 10,13 \\
\hline
\end{tabular}

Tabel 6. Hasil pengukuran $R_{\text {(pembumian) }}$ untuk Elektroda Pasak Tunggal $2 \mathrm{~m}$.

\begin{tabular}{|c|c|c|c|c|}
\hline \multirow{2}{*}{$\begin{array}{c}\text { Kedalaman } \\
\text { Elektroda } \\
(\mathrm{m})\end{array}$} & \multicolumn{4}{|c|}{ Nilai Pengukuran $\mathrm{R}_{\text {(pembumian) }}(\Omega)$} \\
\cline { 2 - 5 } & $\mathrm{I}$ & $\mathrm{II}$ & $\mathrm{III}$ & Rata-rata \\
\hline 2,25 & 14,6 & 14,1 & 14,3 & 14,33 \\
\hline 2,5 & 13,5 & 13,7 & 13,8 & 13,66 \\
\hline 2,75 & 13 & 13,1 & 13,3 & 13,13 \\
\hline 3 & 12,4 & 12,6 & 12,9 & 12,63 \\
\hline 3,25 & 11,9 & 12 & 12,2 & 12 \\
\hline 3,5 & 11,5 & 11,7 & 11,8 & 11,66 \\
\hline 3,75 & 11 & 11,2 & 11,4 & 11,2 \\
\hline 4 & 10,3 & 10,8 & 10,7 & 10,6 \\
\hline 4,25 & 9,9 & 10,2 & 10 & 10 \\
\hline 4,5 & 9,5 & 9,7 & 9,5 & 9,56 \\
\hline
\end{tabular}

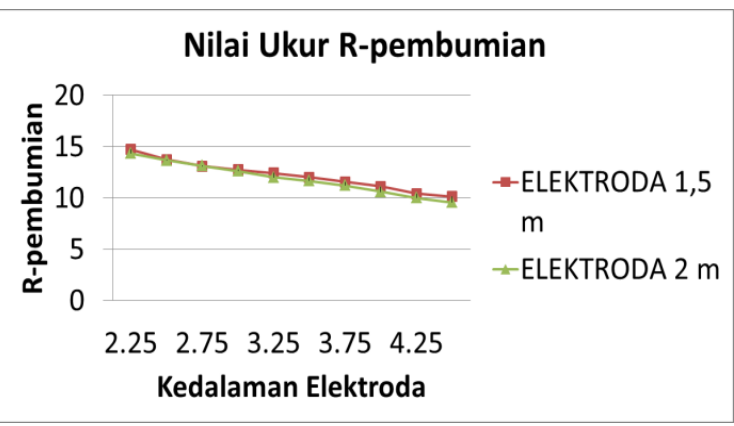

Gambar 2. Grafik Nilai Ukur Tahanan Pembumian

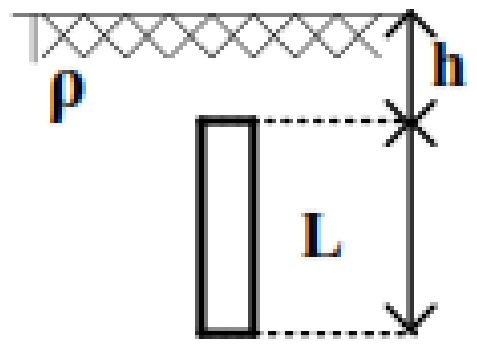

Gambar 3. Desain pemasangan elektroda pasak

Data hasil pengukuran tahanan pembumian elektroda pasak tunggal diuji dengan melakukan perhitungan menggunakan persamaan (1) dan hasil perhitungan nilai rata-rata tahanan jenis tanah liat berlumpur $(\rho)$ dengan variasi kedalaman di lokasi Gedung Laboratorium Teknik Universitas Borneo Tarakan diperoleh sebesar 38,58 $\Omega-\mathrm{m}$ dan 38,84 $\Omega-\mathrm{m}$ dan hasil perhitungan Nilai $R_{(\text {pembumian) }}$ disajikan dalam bentuk berikut : 


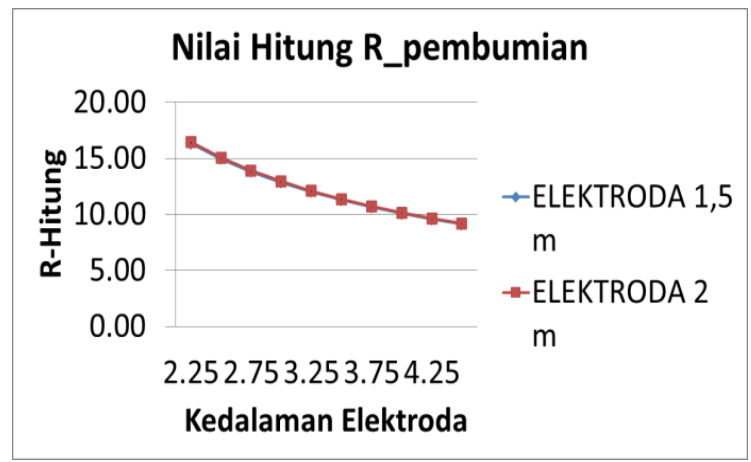

Gambar 4. Grafik Nilai Hitung Tahanan Pembumian

Tabel 7. Hasil nilai perhitungan $\mathrm{R}_{\text {(pembumian) }}$ untuk Elektroda Pasak Tunggal 1,5 m.

\begin{tabular}{|c|c|}
\hline $\begin{array}{c}\text { Kedalaman Elektroda } \\
(\mathrm{m})\end{array}$ & $\begin{array}{c}\text { Hasil Nilai Perhitungan } \\
\mathrm{R}_{(\text {pembumian }}(\Omega)\end{array}$ \\
\hline 2,25 & 16,35 \\
\hline 2,5 & 14,98 \\
\hline 2,75 & 13,83 \\
\hline 3 & 12,85 \\
\hline 3,25 & 12,02 \\
\hline 3,5 & 11,29 \\
\hline 3,75 & 10,65 \\
\hline 4 & 10,08 \\
\hline 4,25 & 9,58 \\
\hline 4,5 & 9,12 \\
\hline
\end{tabular}

Tabel 8. Hasil nilai perhitungan $\mathrm{R}_{\text {(pembumian) }}$ untuk Elektroda Pasak Tunggal $2 \mathrm{~m}$.

\begin{tabular}{|c|c|}
\hline Kedalaman Elektroda $(\mathrm{m})$ & $\begin{array}{c}\text { Hasil Nilai Perhitungan } \\
\mathrm{R}_{\text {(pembumian) }}(\Omega)\end{array}$ \\
\hline 2,25 & 16,46 \\
\hline 2,5 & 15,08 \\
\hline 2,75 & 13,92 \\
\hline 3 & 12,94 \\
\hline 3,25 & 12,10 \\
\hline 3,5 & 11,37 \\
\hline 3,75 & 10,72 \\
\hline 4 & 10,15 \\
\hline 4,25 & 9,64 \\
\hline 4,5 & 9,19 \\
\hline
\end{tabular}

Untuk perbandingan nilai ukur dan hasil perhitungan $\mathrm{R}_{\text {(pembumian) }}$ untuk elektroda pasak 1,5 $\mathrm{m}$ dan $2 \mathrm{~m}$ dapat dilihat pada tabel berikut ini.
Tabel 9. Hasil perbandingan $\mathbf{R}_{\text {(pembumian) }}$ untuk Elektroda Pasak Tunggal 1,5 m.

\begin{tabular}{|c|c|c|c|}
\hline $\begin{array}{c}\text { Kedalaman } \\
\text { Elektroda } \\
(\mathrm{m})\end{array}$ & $\begin{array}{c}\text { Hasil Nilai } \\
\text { Pengukuran } \\
\mathrm{R}_{\text {(pembumian) }}(\Omega)\end{array}$ & $\begin{array}{c}\text { Hasil Nilai } \\
\text { Perhitungan } \\
\mathrm{R}_{\text {(pembumian) }} \\
(\Omega)\end{array}$ & $\begin{array}{c}\text { Selisih } \\
(\%)\end{array}$ \\
\hline 2,25 & 14,73 & 16,35 & $9,92 \%$ \\
\hline 2,5 & 13,73 & 14,98 & $8,32 \%$ \\
\hline 2,75 & 13,1 & 13,83 & $5,27 \%$ \\
\hline 3 & 12,76 & 12,85 & $0,73 \%$ \\
\hline 3,25 & 12,43 & 12,02 & $3,44 \%$ \\
\hline 3,5 & 12 & 11,29 & $6,30 \%$ \\
\hline 3,75 & 11,56 & 10,65 & $8,55 \%$ \\
\hline 4 & 11,13 & 10,08 & $10,38 \%$ \\
\hline 4,25 & 10,43 & 9,58 & $8,90 \%$ \\
\hline 4,5 & 10,13 & 9,12 & $11,03 \%$ \\
\hline
\end{tabular}

Tabel 10. Hasil perbandingan $\mathrm{R}_{\text {(pembumian) }}$ untuk Elektroda Pasak Tunggal $2 \mathrm{~m}$.

\begin{tabular}{|c|c|c|c|}
\hline $\begin{array}{c}\text { Kedalaman } \\
\text { Elektroda } \\
(\mathrm{m})\end{array}$ & $\begin{array}{c}\text { Hasil Nilai } \\
\text { Pengukuran } \\
\mathrm{R}_{\text {(pembumian) }} \\
(\Omega)\end{array}$ & $\begin{array}{c}\text { Hasil Nilai } \\
\text { Perhitungan } \\
\mathrm{R}_{\text {(pembumian) }} \\
(\Omega)\end{array}$ & $\begin{array}{c}\text { Selisih } \\
(\%)\end{array}$ \\
\hline 2,25 & 14,33 & 16,46 & $12,95 \%$ \\
\hline 2,5 & 13,66 & 15,08 & $9,40 \%$ \\
\hline 2,75 & 13,13 & 13,92 & $5,68 \%$ \\
\hline 3 & 12,63 & 12,94 & $2,40 \%$ \\
\hline 3,25 & 12 & 12,10 & $0,81 \%$ \\
\hline 3,5 & 11,66 & 11,37 & $2,59 \%$ \\
\hline 3,75 & 11,2 & 10,72 & $4,46 \%$ \\
\hline 4 & 10,6 & 10,15 & $4,42 \%$ \\
\hline 4,25 & 10 & 9,64 & $3,71 \%$ \\
\hline 4,5 & 9,56 & 9,19 & $4,08 \%$ \\
\hline
\end{tabular}

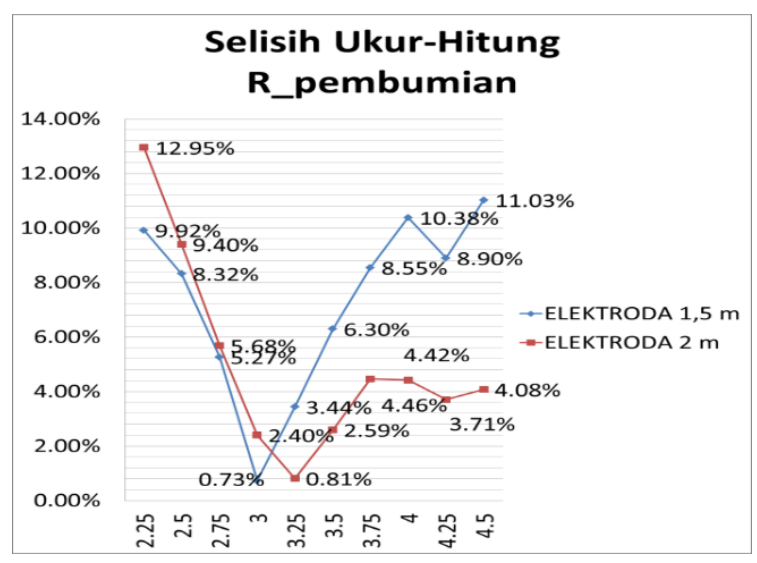

Gambar 5. Grafik Prosentase Selisih Nilai Ukur dan Hitung Tahanan Pembumian

Dari tabel perbandingan, diketahui selisih terkecil antara nilai pengukuran dan nilai perhitungan $\mathrm{R}_{\text {(pembumian) }}$ elektroda pasak 1,5 m 
adalah $0,73 \%$ atau $0,09 \Omega$ pada kedalaman $3 \mathrm{~m}$ dengan Nilai ukur-hitung $\mathrm{R}_{\text {(pembumian) }}$ elektroda pasak $1,5 \mathrm{~m}$ masing-masing $12,76 \Omega$ dan 12,85 $\Omega$ sedangkan elektroda pasak $2 \mathrm{~m}$ adalah $0,81 \%$ atau $0,10 \Omega$ pada kedalaman $3,25 \mathrm{~m}$ mempunyai Nilai ukur-hitung $\mathrm{R}_{\text {(pembumian) }}$ elektroda pasak $2 \mathrm{~m}$ masing-masing $12 \Omega$ dan $12,10 \Omega$.

Berdasarkan hasil perbandingan tersebut maka selisih (Error) ukur-hitung terkecil merupakan yang paling baik yaitu elektroda pasak $1,5 \mathrm{~m}$ adalah $0,73 \%$ atau $0,09 \Omega$ pada kedalaman $3 \mathrm{~m}$ dengan $\mathrm{R}_{\text {(pembumian) }}$ pengukuran 12,76 $\Omega$.

Untuk mencapai $\mathrm{R}_{\text {(pembumian) }} \leq 5 \Omega$ yang sesuai dengan Persyaratan Umum Instalasi Listrik [2] maka elektroda pasak $1,5 \mathrm{~m}$ dengan nilai $\mathrm{R}_{\text {(pembumian) }}$ pengukuran $12,76 \Omega$ disusun secara paralel agar mencapai nilai $\mathrm{R}_{\text {(pembumian) }}$ sebesar 5 $\Omega$ menggunakan persamaan (2).

$\frac{1}{R_{\text {Total }}}=\frac{1}{12,76}+\frac{1}{12,76}$

$R_{\text {Total }}=6,43 \Omega$

Hasil perhitungan $\mathbf{R}_{\text {(pembumian) }}$ susun paralel untuk 2 buah elektroda adalah $6,43 \Omega$ dan selanjutnya dapat dilihat pada Tabel 11 .

Tabel 11. Nilai $\mathbf{R}_{\text {(pembumian) }}$ untuk Elektroda Pasak Tunggal 1,5 m hubung paralel.

\begin{tabular}{|c|c|}
\hline $\begin{array}{c}\text { Jumlah Elektroda } \\
\text { Pasak }\end{array}$ & $\begin{array}{c}\text { Nilai } \mathrm{R}_{(\text {pembumian) }} \text { hubung } \\
\operatorname{paralel}(\Omega)\end{array}$ \\
\hline 2 & 6,43 \\
\hline 3 & 4,28 \\
\hline 4 & 3,21 \\
\hline
\end{tabular}

Berdasarkan Tabel 11 diketahui pemasangan electrode pasak 1,5 m sebanyak 3 buah secara paralel mempunyai nilai $\mathbf{R}_{\text {(pembumian) }}$ sebesar 4,28 $\Omega$ memenuhi Persyaratan Umum Instalasi Listrik dan jarak minimum pemasangan antar elektroda sebesar 2 (dua) kali panjangnya.

\section{KESIMPULAN}

1. Kadar air tinggi pada tanah dapat memperkecil nilai tahanan pembumian dan air merupakan konduktor yang baik dalam mengalirkan arus listrik.

2. Nilai pengukuran $\mathbf{R}_{\text {(pembumian) }}$ elektroda pasak $1,5 \mathrm{~m}$ dan hasil perhitungannya masingmasing sebesar $12,76 \Omega$ dan $12,85 \Omega$ dengan nilai rata-rata tahanan jenis tanah liat berlumpur $(\rho)=38,58 \Omega$-m.

3. Nilai pengukuran $R_{\text {(pembumian) }}$ elektroda pasak 2 $\mathrm{m}$ dan hasil perhitungannya masing-masing sebesar $12 \Omega$ dan $12,10 \Omega$ dengan nilai ratarata tahanan jenis tanah liat berlumpur $(\rho)=$ $38,84 \Omega-\mathrm{m}$

4. Hasil perbandingan elektroda pasak $1,5 \mathrm{~m}$ dengan elektroda pasak $2 \mathrm{~m}$ diperoleh bahwa selisih (Error) ukur-hitung terkecil merupakan yang paling baik yaitu elektroda pasak $1,5 \mathrm{~m}$ adalah $0,73 \%$ atau $0,09 \Omega$ pada kedalaman 3 m dengan $R_{\text {(pembumian) }}$ pengukuran $12,76 \Omega$.

5. Pemasangan elektroda pasak $1,5 \mathrm{~m}$ sebanyak 3 buah secara paralel mempunyai nilai $\mathrm{R}_{\text {(pembumian) }} \quad$ sebesar $\quad 4,28 \quad \Omega \quad$ memenuhi Persyaratan Umum Instalasi Listrik dan jarak minimum pemasangan antar elektroda sebesar 2 (dua) kali panjangnya.

\section{DAFTAR PUSTAKA}

[1] Asep Dadan Hermawan. (2010). Optimalisasi Sistem Penangkal Petir Eksternal Menggunakan Jenis Early Streamer (Studi Kasus UPT LAGG $B P P T)$. Universitas Indonesia, Jakarta, (2010).

[2] Badan Standarisi Nasional (BSN). 2000. Persyaratan Umum Instalasi Listrik 2000 (PUIL 2000). Jakarta: Yayasan PUIL, (2000).

[3] Hutauruk, T.S., Pengetanahan Netral Sistem Tenaga dan Pengetanahan Peralatan. Erlangga, Jakarta, (1991).

[4] IEEE Std 142-2007. IEEE Recommended Practice for Grounding of Industrial and Commercial Power Systems, (2007).

[5] Linda Pasaribu, Studi Analisis Pengaruh Jenis Tanah, Kelembaban, Temperatur dan Kadar Garam Terhadap Tahanan Pentanahan Tanah (Tesis). Universitas Indonesia, Jakarta, (2011).

[6] Muhammad Taqiyyuddin Alawiy, Pengaruh Kedalaman Penanaman dan Jarak Elektroda Tambahan Terhadap Nilai Tahanan Pembumian, Universitas Islam, Malang, . (2013).

[7] Managam Rajagukguk, Studi Pengaruh Jenis Tanah dan Kedalaman Pembumian Driven Rod terhadap Resistansi Jenis 
Tanah, Universitas Tanjungpura, Pontianak, (2012).

[8] Mirwan Mukmin, Perbandingan Nilai Tahanan Pada Area Reklamasi Pantai (Citraland). Universitas Tadulako, Palu (2014).

\section{Biodata Penulis}

Achmad Budiman, Program Studi Teknik Elektro, Universitas Borneo Tarakan, Jalan Amal Lama No.1 Tarakan. 